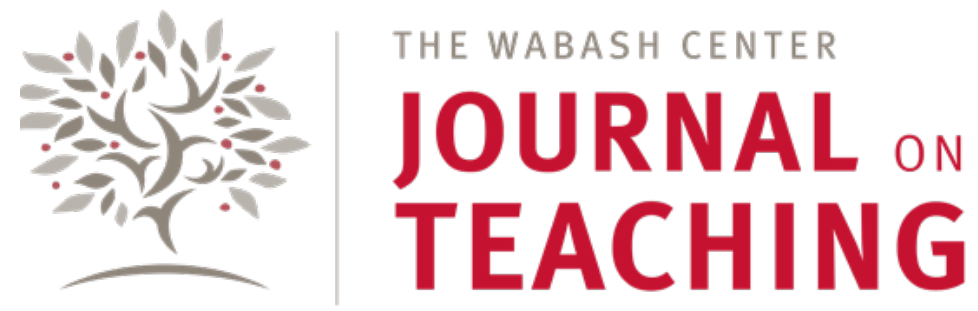

\title{
SPECIAL TOPIC \\ Introduction to the Special Section on Critical Incidents in Teaching
}

Thomas Pearson, Editor

\begin{abstract}
The three short essays gathered in this Special Topic were submitted in response to the journal's Call for Papers on Critical Incidents in Teaching. A “critical incident” is a memorable, significant, or unexpected moment experienced in the classroom. Subjecting such moments to careful critical analysis can reveal important facets of the purposes and practices of teaching. Essays by Alison Downie, ("Who Speaks When?"), Eunyung Lim (“Teaching 'Greek for Ministry' in a Multicultural Classroom”), and Nermeen Mouftah (“"I Want to Love Islam, I Really Do, But. . .': Islamophilic Classrooms in Islamophobic Times”).
\end{abstract}

\section{KEYWORDS}

Stephen Brookfield, critical incident questionnaire, writing prompts for scholarship of teaching

The three short manuscripts published in this Special Topic section were submitted in response to the journal's 2019 call for papers, requesting short manuscripts that describe and analyze a particular critical incident in teaching. A "critical incident" is a memorable, significant, or unexpected moment in the classroom. Subjecting such moments to careful critical analysis can reveal important facets of the purposes and practices of teaching.

The call for papers was inspired by Stephen Brookfield's discussion of "critical incident questionnaires," designed to help students to become more reflective learners (1995, 114-139). The call for papers asked authors to become more reflective teachers by unpacking the learning processes in a particular classroom moment.

Each of the essays first provides a factually based description of the event-the who, what, when, where, and why of the incident (like the prologue to any good novel, play, or movie). Then the essays move to an analysis of what this incident means to the author-teacher. The essays show how the authors puzzled through the various complicating factors that made decision making in this situation a more difficult process than it originally might have appeared to be on the surface. Third, the essays reveal what the author has learned from the incident. "What do I know now that I wish I knew then; and, had I known it, how might I have perhaps acted differently?" The essays conclude by identifying the personal and professional tools, skills, and attributes that one needs in order to meet the challenges presented by the critical incident.

Although this is not currently a specific call for papers, the journal would always welcome submission of manuscripts of 5,000 words or more developed along similar lines using these writing prompts. 


\section{ESSAYS INCLUDED IN THIS SPECIAL TOPIC SECTION}

Downie, Alison. 2020. “Who Speaks When?” The Wabash Center Journal on Teaching 1 (2): 41-48. https://doi.org/10.31046/wabashcenter.v1i2.1717.

Lim, Eunyung. 2020. “Teaching ‘Greek for Ministry’ in a Multicultural Classroom.” The Wabash Center Journal on Teaching 1 (2): 49-54. https://doi.org/10.31046/wabashcenter.v1i2.1718.

Mouftah, Nermeen. 2020. “'I Want to Love Islam, I Really Do. But . . . ': Islamophilic Classrooms in Islamophobic Times.” The Wabash Center Journal on Teaching 1 (2): 55-62. https://doi.org/10.31046/wabashcenter.v1i2.1716.

\section{BIBLIOGRAPHY}

Brookfield, Stephen. 1995. “Understanding Classroom Dynamics: The Critical Incident Questionnaire.” Becoming a Critically Reflective Teacher, 114-139. San Francisco, CA: Jossey-Bass.

Kwok, Pui Lan, William P. Brown, Steve Delamarter, Thomas E. Frank, Joretta L. Marshall, Esther Menn, and Marcia Y. Riggs. 2005. "Taken with Surprise: Critical Incidents in Teaching." Teaching Theology and Religion 8 (1): 35-46.https://doi.org/10.1111/i.1467-9647.2005.00223.x. 